\title{
Data Report: Meteorological and Evapotranspiration Data from Sagebrush and Pinyon Pine/Juniper Communities at Pahute Mesa, Nevada National Security Site, 2011-2012
}

\author{
prepared by \\ Richard L. Jasoni, Jessica D. Larsen, Brad F. Lyles, John M. Healey, \\ Clay A. Cooper, and Ronald L. Hershey \\ submitted to \\ Nevada Site Office \\ National Nuclear Security Administration \\ U.S. Department of Energy \\ Las Vegas, Nevada
}

April 2013

PUBLICATION \#45248 
Reference herein to any specific commercial product, process, or service by trade name, trademark, manufacturer, or otherwise, does not necessarily constitute or imply its endorsement, recommendation, or favoring by the United States Government or any agency thereof or its contractors or subcontractors.

Available for sale to the public from:

\author{
U.S. Department of Commerce \\ National Technical Information Service \\ 5301 Shawnee Road \\ Alexandria, VA 22312 \\ Phone: 800.553.6847 \\ Fax: 703.605.6900 \\ Email: orders@ntis.gov \\ Online ordering: http://www.osti.gov/ordering.htm
}

Available electronically at http://www.osti.gov/bridge.

Available for a processing fee to the U.S. Department of Energy and its contractors, in paper, from:

\author{
U.S. Department of Energy \\ Office of Scientific and Technical Information \\ P.O. Box 62 \\ Oak Ridge, TN 37831-0062 \\ Phone: 865.576.8401 \\ Fax: 865.576.5728 \\ Email: reports@adonis.osti.gov
}




\title{
Data Report: Meteorological and Evapotranspiration Data from Sagebrush and Pinyon Pine/Juniper Communities at Pahute Mesa, Nevada National Security Site, 2011-2012
}

\author{
prepared by \\ Richard L. Jasoni, Jessica D. Larsen, Brad F. Lyles, John M. Healey, \\ Clay A. Cooper, and Ronald L. Hershey \\ Division of Hydrologic Sciences, Desert Research Institute \\ Nevada System of Higher Education
}

Publication No. 45248

submitted to

Nevada Site Office

National Nuclear Security Administration

U.S. Department of Energy

Las Vegas, Nevada

April 2013

The work upon which this report is based was supported by the U.S. Department of Energy under Contract \#DE-NA0000939. Approved for public release; further dissemination unlimited. 
THIS PAGE INTENTIONALLY LEFT BLANK 


\begin{abstract}
Pahute Mesa is a groundwater recharge area at the Nevada National Security Site. Because underground nuclear testing was conducted at Pahute Mesa, groundwater recharge may transport radionuclides from underground test sites downward to the water table; the amount of groundwater recharge is also an important component of contaminant transport models. To estimate the amount of groundwater recharge at Pahute Mesa, an INFIL3.0 recharge-runoff model is being developed. Two eddy covariance (EC) stations were installed on Pahute Mesa to estimate evapotranspiration (ET) to support the groundwater recharge modeling project. This data report describes the methods that were used to estimate ET and collect meteorological data. Evapotranspiration was estimated for two predominant plant communities on Pahute Mesa; one site was located in a sagebrush plant community, the other site in a pinyon pine/juniper community. Annual ET was estimated to be $310 \pm 13.9 \mathrm{~mm}$ for the sagebrush site and 347 $\pm 15.9 \mathrm{~mm}$ for the pinyon pine/juniper site (March 26, 2011 to March 26, 2012). Annual precipitation measured with unheated tipping bucket rain gauges was $179 \mathrm{~mm}$ at the sagebrush site and $159 \mathrm{~mm}$ at the pinyon pine/juniper site. Annual precipitation measured with bulk precipitation gauges was $222 \mathrm{~mm}$ at the sagebrush site and $227 \mathrm{~mm}$ at the pinyon pine/juniper site (March 21, 2011 to March 28, 2012). A comparison of tipping bucket versus bulk precipitation data showed that total precipitation measured by the tipping bucket rain gauges was 17 to 20 percent lower than the bulk precipitation gauges. These differences were most likely the result of the unheated tipping bucket precipitation gauges not measuring frozen precipitation as accurately as the bulk precipitation gauges. In this one-year study, ET exceeded precipitation at both study sites because estimates of ET included precipitation that fell during the winter of 2010-2011 prior to EC instrumentation and the precipitation gauges started collecting data in March 2011.
\end{abstract}


THIS PAGE INTENTIONALLY LEFT BLANK 


\section{CONTENTS}

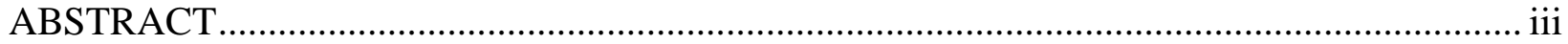

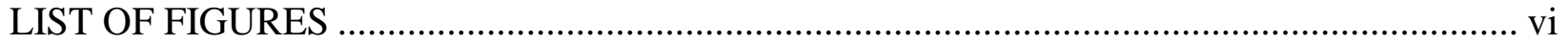

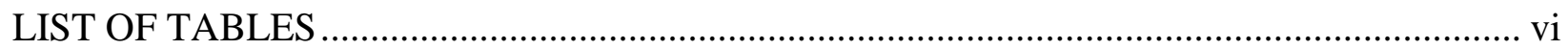

LIST OF ACRONYMS ................................................................................................... vii

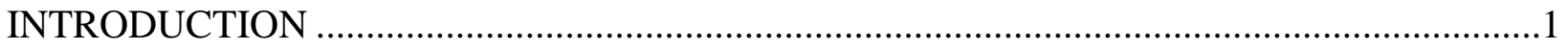

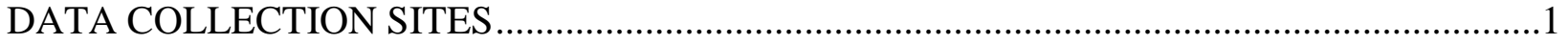

EDDY COVARIANCE INSTRUMENTATION AND CALCULATIONS...................................

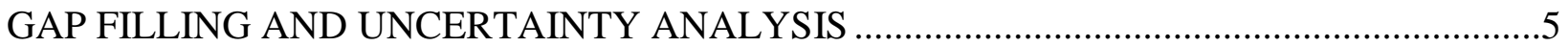

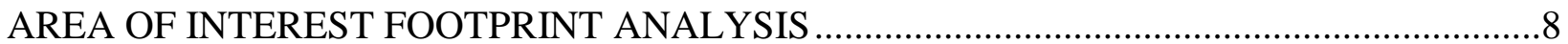

AIR TEMPERATURE, SOIL TEMPERATURE AND MOISTURE, NET RADIATION,

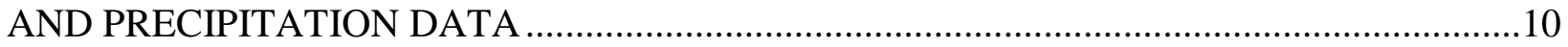

EVAPOTRANSPIRATION DATA ………………........................................................12

COMPARISON OF TIPPING BUCKET AND BULK GAUGE PRECIPITATION DATA ......14

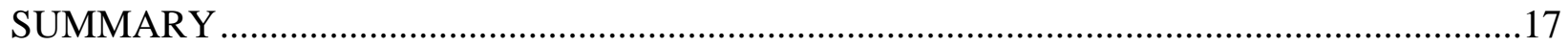

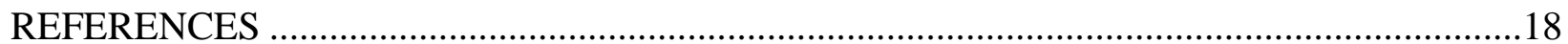




\section{LIST OF FIGURES}

1. Map showing the location of the sagebrush and pinyon pine/juniper eddy covariance evapotranspiration sites at Pahute Mesa, Nevada National Security Site.

2. Photographs of the sagebrush (a) and pinyon pine/juniper (b) eddy covariance and meteorological instrumentation located at Pahute Mesa.

3. Site-specific regression of ET vs. PFD of PAR for the sagebrush site located at Pahute Mesa

4. Site-specific regression of ET vs. PFD of PAR for the pinyon/juniper site located at

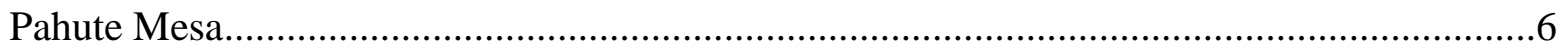

5. Area of interest footprint for the sagebrush site located at Pahute Mesa..............................9

6. Area of interest footprint for the pinyon pine/juniper site located at Pahute Mesa................10

7. Mean daily air temperature, soil temperature, soil moisture, and net radiation measured at the sagebrush and pinyon pine juniper sites located at Pahute Mesa between March 26, 2011 and March 26, 2012.

8. Daily evapotranspiration and daily precipitation for the sagebrush and pinyon pine/juniper sites located at Pahute Mesa during the one-year study....

9. Response of available energy, latent energy, and sensible heat fluxes to precipitation events between the dates of July 1 and July 13, 2011 at the sagebrush site located on Pahute Mesa.

\section{LIST OF TABLES}

1. Total systematic uncertainty of annual evapotranspiration ( $\mathrm{mm}$ ) calculated as the square root of the sum of squared individual sources of uncertainty..

2. Study-year: average air temperature, air vapor pressure, air vapor pressure deficit, soil temperature, and total precipitation for the sagebrush and pinyon pine/juniper sites.

3. Monthly evapotranspiration values for the sagebrush and pinyon pine/juniper sites located at Pahute Mesa between March 26, 2011 and March 26, 2012.

4. Precipitation data for select gauges at the NNSS from October 2010 through March 2011.

5. Comparison of unheated tipping bucket and bulk precipitation gauges located at both the sagebrush and pinyon pine/juniper sites at Pahute Mesa, Nevada. 


\section{LIST OF ACRONYMS}

$\begin{array}{ll}\text { AGC } & \text { automatic gain control } \\ \text { d } & \text { day } \\ \text { DOE } & \text { U.S. Department of Energy } \\ \text { EC } & \text { Eddy Covariance } \\ \text { ET } & \text { Evapotranspiration } \\ \text { H } & \text { Sensible heat } \\ \mathrm{H}_{2} \mathrm{O} & \text { Water } \\ \mathrm{Hz} & \text { Hertz } \\ \text { IRGA } & \text { infrared gas analyzer } \\ \text { kg } & \text { kilogram } \\ \text { kPa } & \text { kilopascal } \\ \text { LE } & \text { Latent energy } \\ \text { m } & \text { meter } \\ \text { mm } & \text { millimeter } \\ \text { NNSS } & \text { Nevada National Security Site } \\ \text { NSO } & \text { Nevada Site Office } \\ \text { NV } & \text { Nevada } \\ \text { PAR } & \text { photosynthetically active radiation } \\ \text { PFD } & \text { photon flux density } \\ \text { RH } & \text { Relative humidity } \\ \text { VPD } & \text { Vapor pressure deficit } \\ \text { UGTA } & \text { Underground Test Area } \\ \text { WPL } & \text { Webb, Pearman, Leuning }\end{array}$


THIS PAGE INTENTIONALLY LEFT BLANK 


\section{INTRODUCTION}

Pahute Mesa is located in the northwest portion of the Nevada National Security Site (NNSS) (Figure 1). Pahute Mesa is a groundwater recharge area for aquifers found at the NNSS. Because underground nuclear testing was conducted at Pahute Mesa, groundwater recharge may transport radionuclides from underground test sites downward to the water table. Quantifying the amount of groundwater recharge at Pahute Mesa is also important because groundwater flow and contaminant transport models are sensitive to groundwater recharge from Pahute Mesa (U.S. Department of Energy, 2009).

To estimate the amount of groundwater recharge at Pahute Mesa, the U.S. Department of Energy (DOE), Nevada Site Office (NSO), Environmental Restoration Program (ERP), Underground Test Area (UGTA) project is developing an INFIL recharge-runoff model (Hevesi et al., 2003). INFIL3.0 is a grid-based, disturbed-parameter, deterministic, water-balance, watershed model that calculates the temporal and spatial distribution of daily net infiltration of water across the lower boundary of the root zone (U.S. Geological Survey, 2008). The daily water balance simulated with INFIL3.0 includes estimates of evapotranspiration (ET) from the root zone. To provide data for the Pahute Mesa INFIL3.0 recharge model, two eddy covariance (EC) stations were installed on Pahute Mesa to estimate ET. The EC method was used to estimate ET for one year at two predominant plant communities (sagebrush and pinyon pine/juniper) on Pahute Mesa.

\section{DATA COLLECTION SITES}

Two study sites were selected at Pahute Mesa that contain sagebrush (Artemisia tridentate) and pinyon pine (Pinus edulis)/juniper (Junipera sp.) plant communities. The sagebrush site was located at $37^{\circ} 14^{\prime} 30.09^{\prime}$ N, $116^{\circ} 28^{\prime} 32.22^{\prime \prime} \mathrm{W}$ (elevation $1915 \mathrm{~m}$ ), and the pinyon pine/juniper site was located at 37²1 $51.39^{\prime \prime} \mathrm{N}, 116^{\circ} 19^{\prime} 58.59^{\prime \prime} \mathrm{W}$ (elevation $2223 \mathrm{~m}$ ) (Figure 1). Average annual precipitation at a long-term precipitation gauge on Pahute Mesa (PM1) (http://www.sord.nv.doe.gov/raingage/Monthly/Pahute_Mesa_Monthly_Data.txt) between 1964 and 2011 was $193 \mathrm{~mm}$ with a range of $67 \mathrm{~mm}$ (2002) to $368 \mathrm{~mm}$ (1999). The gauge at PM1 was a universal weighing rain gauge until September, 2011 when it was replaced with an M29 electronic tipping bucket gauge. The PM1 precipitation gauge is located at $37^{\circ} 15^{\prime} 23.6^{\prime \prime} \mathrm{N}, 116^{\circ} 26^{\prime} 07.06^{\prime \prime} \mathrm{W}$ (elevation $1996 \mathrm{~m}$ ) and was approximately $4 \mathrm{~km}$ from the sagebrush site and $10 \mathrm{~km}$ from the pinyon pine/juniper site.

\section{EDDY COVARIANCE INSTRUMENTATION AND CALCULATIONS}

Eddy covariance, energy balance, and meteorological instruments were installed at the sagebrush and pinyon pine/juniper sites on February 18, 2011, but initial data collection was not initiated until March 26, 2011 (Figure 1 and Figure 2). A 3 m tower was installed at the sagebrush site while a $10 \mathrm{~m}$ tower was installed at the pinyon pine/juniper site so that the eddy covariance (EC) instrumentation was above the taller the pinyon pine/juniper vegetation; these 


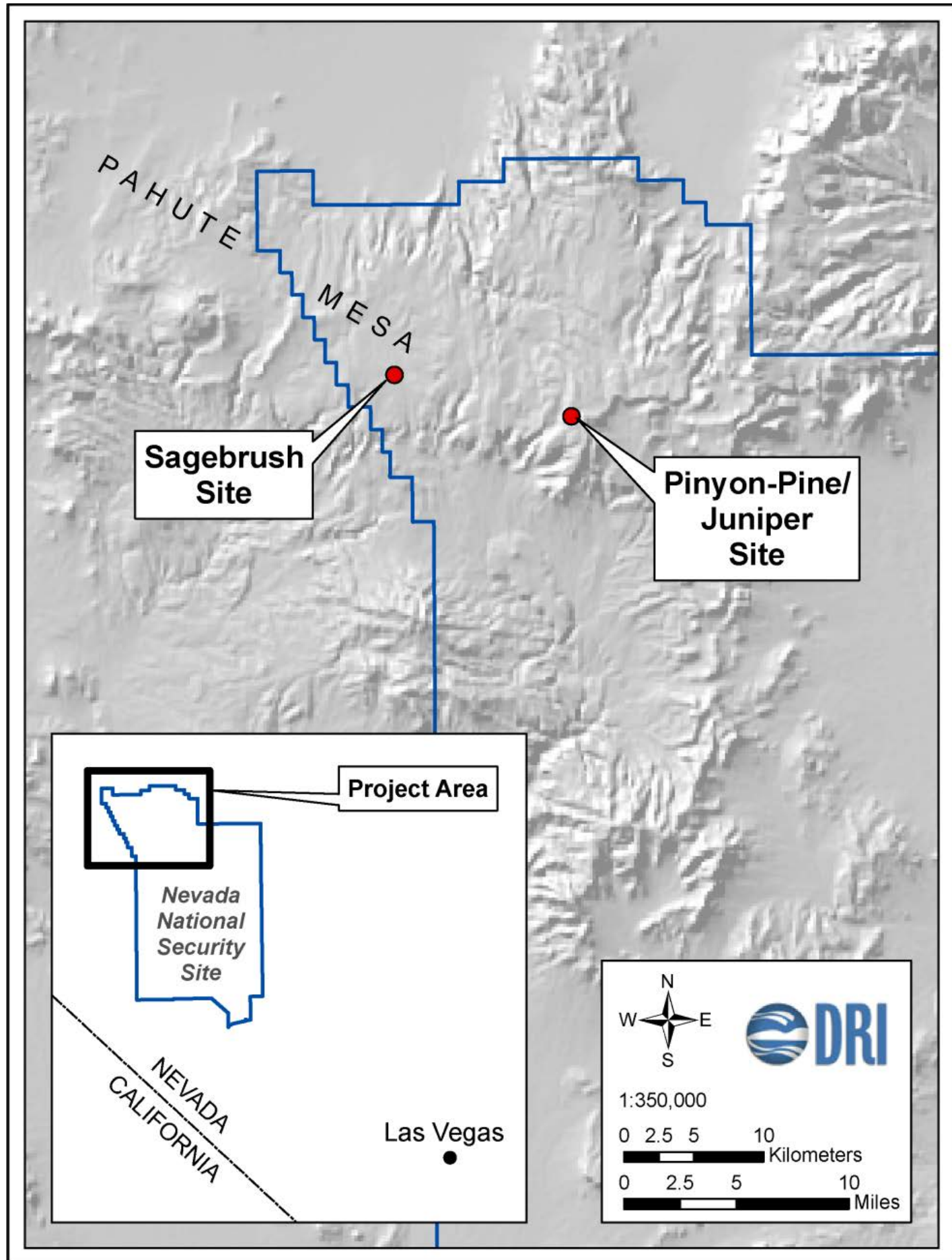

Figure 1. Map showing the location of the sagebrush (37¹4'30.09” N, $116^{\circ} 28^{\prime} 32.22^{\prime \prime} \mathrm{W}$; elevation $1915 \mathrm{~m})$ and pinyon pine/juniper $\left(37^{\circ} 12^{\prime} 51.39^{\prime \prime} \mathrm{N}, 116^{\circ} 19^{\prime} 58.59^{\prime \prime} \mathrm{W}\right.$; elevation $2223 \mathrm{~m}$ ) eddy covariance evapotranspiration sites at Pahute Mesa, Nevada National Security Site. 

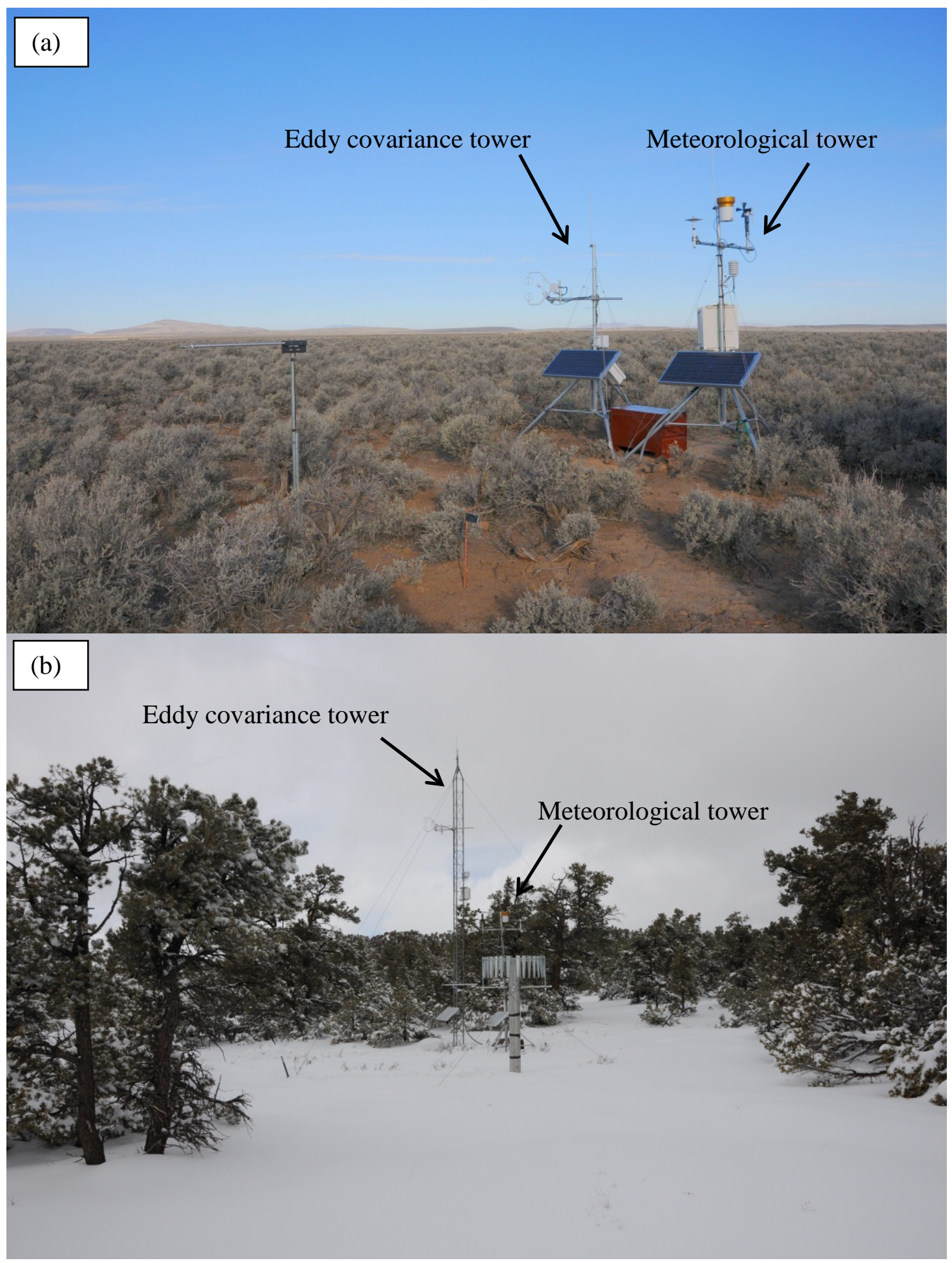

Figure 2. Photographs of the sagebrush (a) and pinyon pine/juniper (b) eddy covariance and meteorological instrumentation located at Pahute Mesa. Photographs were taken by Brad Lyles of the Desert Research Institute on February 18, 2011 for the sagebrush site and on March 24, 2011 for the pinyon pine/juniper site. 
EC towers were installed to estimate ET from the dominant vegetation cover at each site. Eddy covariance instrumentation consisted of a three-dimensional sonic anemometer (CSAT3, Campbell Scientific Inc., Logan, Utah, USA) to measure the three wind components and an open-path infrared gas analyzer (IRGA) to measure $\mathrm{H}_{2} \mathrm{O}$ molar density (LI-7500, LI-COR Inc., Lincoln, Nebraska, USA). The EC instrumentation was mounted 1.4 and $2.7 \mathrm{~m}$ above mean vegetation height on the south (predominant wind direction) side of the sagebrush and pinyon pine/juniper towers, respectively. The sensor heights above mean vegetation height were selected to increase the number of points within the area of interest/footprint (sagebrush or pinyon pine/juniper communities) and to avoid interference from sources outside of this area. The ensuing larger high-frequency flux contributions and unavoidable low-pass filtering caused by the sensor heights were accounted for during post-processing using the method described by Massman (2000).

Meteorological instruments at both sites were mounted on an adjacent $3 \mathrm{~m}$ tower and consisted of a shielded air temperature and humidity sensor (HMP-45C, Viasala, Finland; mounted $2.0 \mathrm{~m}$ above ground surface), a wind vane anemometer (RM Young Wind Sentry, RM Young Company, Traverse City, MI, USA; mounted 1.5 and $2.1 \mathrm{~m}$ above ground surface at the sagebrush and pinyon pine/juniper sites, respectively), a net radiometer (NR-Lite, Kipp \& Zonen, The Netherlands; mounted $1.8 \mathrm{~m}$ above ground surface), a photosynthetically active radiation sensor (Q-190-SB, LI-COR Inc.; PAR, 400-700 nm; mounted $2.5 \mathrm{~m}$ above ground surface), an unheated tipping bucket rain gauge (TE525, Texas Electronics, Dallas, TX, USA; mounted $2.5 \mathrm{~m}$ above ground surface), and a bulk precipitation gauge (bulk gauges were fabricated as part of this project from $20 \mathrm{~cm}$ diameter stainless steel pipe and fitted with a standard alter shield [model 260-952, NovaLynx Corporation, Grass Valley, CA, USA]). The gauge orifice was approximately $1.8 \mathrm{~m}$ above the ground surface, and the top of the alter shield was about $5 \mathrm{~cm}$ above the gauge orifice. Soils instrumentation included two soil heat flux plates (Hukseflux HFP01SC, HuksefluxUSA, Manoville, NY; inserted at $8 \mathrm{~cm}$ soil depth), soil temperature thermocouple probes (TCAV averaging soil thermocouple probes, Campbell Scientific; installed at 2 and $6 \mathrm{~cm}$ soil depth adjacent to the soil heat flux plate), and a water content reflectometer (CS-616, Campbell Scientific; installed at a depth of $4 \mathrm{~cm}$ ). Data from the EC instrumentation were recorded at a frequency of $10 \mathrm{~Hz}$ (10 times per second) while data from the other instrumentation were recorded as 30-min averages, and both sets of data were logged using a CR5000 data logger (Campbell Scientific). Both the $10 \mathrm{~Hz}$ data and 30-min average data were stored on a compact flash card. Data from the compact flash card were downloaded monthly when instruments were checked and maintained.

Eddy fluxes were calculated as the covariance between turbulent fluctuations of the vertical wind speed and water vapor density derived from Reynolds (block) averaging of 30-min blocks of data. The sonic anemometer's coordinate system was numerically rotated during each averaging period by applying a double rotation, aligning the longitudinal wind component into the main wind direction, and forcing the mean vertical wind speed to zero (Kaimal and Finnigan, 1994; Wohlfahrt et al., 2008). Frequency response corrections were applied to raw eddy fluxes 
accounting for low-pass (lateral and longitudinal sensor separation, sensor time response, scalar and vector path averaging) and high-pass (block averaging) filtering (Massman, 2000, 2001) using a site-specific, co-spectral reference model (Massman and Clement, 2004; Wohlfahrt et al., 2005). Experimentally-derived frequency response correction factors (Aubinet et al., 2000, 2001) were used to assess the validity of the theoretical low-pass filtering correction method as detailed in Wohlfahrt et al. (2005). Finally, fluxes were corrected for the effect of air density fluctuations following Webb et al. (1980).

Half-hourly flux data were quality controlled in a five-step filtering procedure. First, periods were identified when the EC system was not working properly because of adverse environmental conditions (usually rain or snow) or instrument malfunction. Second, half-hourly values that were comprised of less than the full complement of measured values (i.e., less than 18,000) were removed. Third, data were subjected to the integral turbulence test (Foken and Wichura, 1996) and accepted only on the condition that they did not exceed the target value (Foken et al., 2004) by more than 60 percent (Wohlfahrt et al., 2008). Fourth, data were subjected to the angle of attack test ( $\beta$ - beta; the angle between the wind vector and horizontal), which identifies errors in data resulting from the imperfect cosine response of sonic anemometers. Data were excluded when the angle of attack was greater than $20^{\circ}$ (Geissbühler et al., 2000; Gash and Dolman, 2003). Finally, data were excluded when the automatic gain control (AGC) of the IRGA was greater than $10 \%$ of the specific baseline value for each instrument. Increases from baseline AGC typically result from rain, snow, or ice accumulation on the surface of the lens of the IRGA and result in errors in water vapor density values.

\section{GAP FILLING AND UNCERTAINTY ANALYSIS}

Data gaps (30-min time steps; both daytime and nighttime values) for each site, resulting from filtering or missing data, were filled using a site-specific regression equation of ET vs. photon flux density (PFD) of photosynthetically active radiation (PAR) (Figure 3 and Figure 4). Seventeen percent of the 30-min values for the sagebrush site were gap filled using the sitespecific regression equation of ET vs. PAR; nine percent of the 30-min values were gap filled for the pinyon pine/juniper site. Photosynthetically active radiation was used because of its relationship to plant physiological processes (e.g., transpiration and stomatal conductance). This method resulted in gap-filled nighttime ET values being zero. Gap filling nighttime values with a site-specific regression using PAR is a conservative approach when compared to other gap filling methods such as linear interpolation or the mean diurnal variation method with a time window of one month (Falge et al., 2001). These methods tend to result in overestimation of nighttime ET. Gap filling 30-min data using net radiation is also a viable gap filling method and site-specific regression equations of ET vs. net radiation measured during this study resulted in similar regressions (sagebrush site: $\mathrm{r}^{2}=0.53, P<0.0001$, slope $=0.0001$, $\mathrm{y}$-int. $=0.0089$; pinyon pine/juniper site: $\mathrm{r}^{2}=0.59, P<0.0001$, slope $=0.0001$, y-int. $=0.011$ ) to those using PAR. 


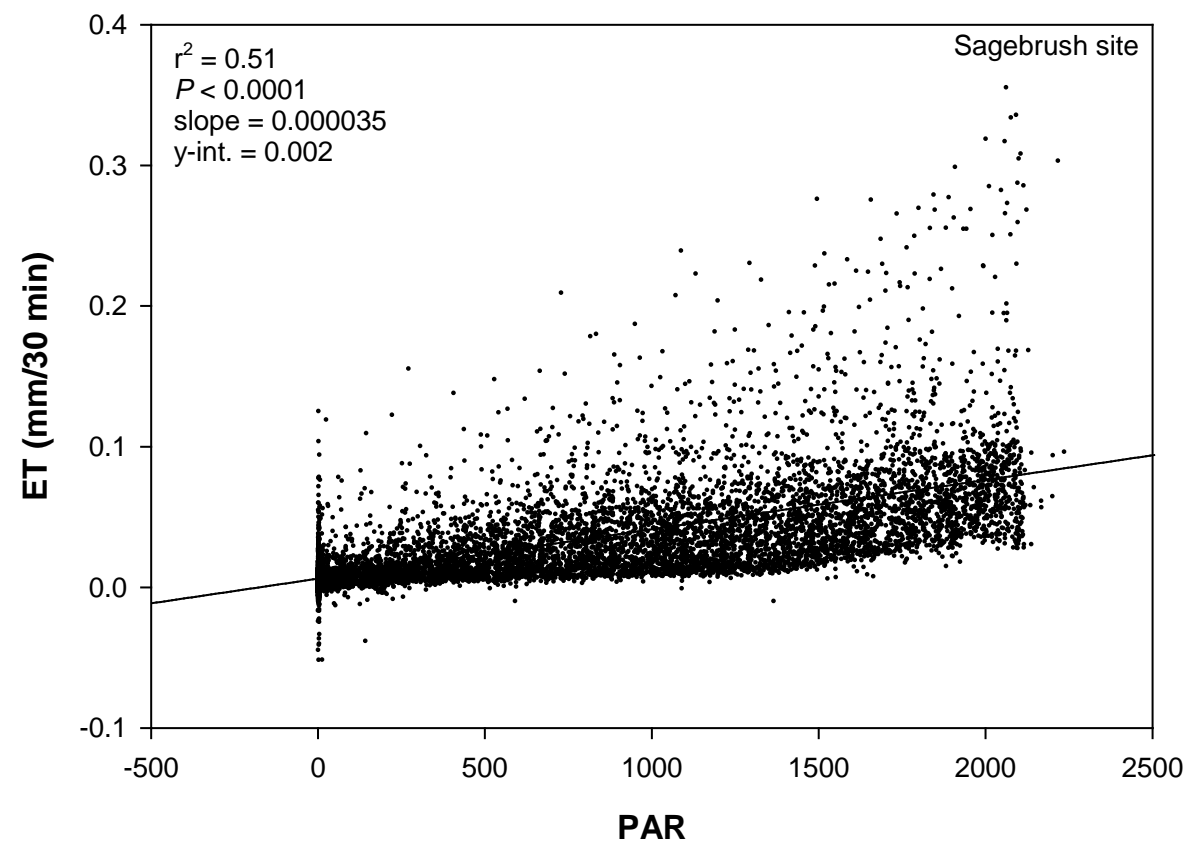

Figure 3. Site-specific regression of ET vs. PFD of PAR for the sagebrush site located at Pahute Mesa (elevation $1915 \mathrm{~m}$ ). Each point represents a 30-min time period between March 26, 2011 and March 26, 2012, and includes both daytime and nighttime values. The resulting regression equation was used to fill gaps in ET data resulting from filtering or missing data.

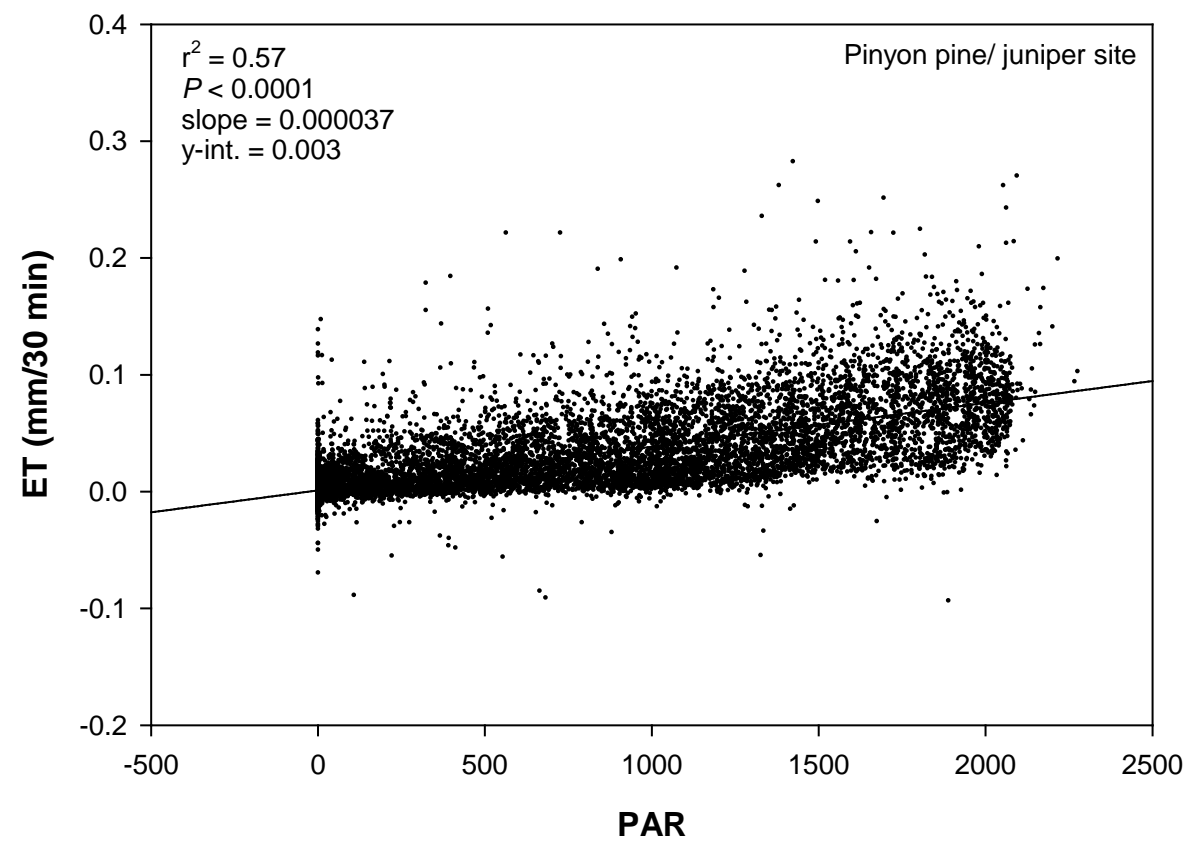

Figure 4. Site-specific regression of ET vs. PFD of PAR for the pinyon/juniper site located at Pahute Mesa (elevation $2223 \mathrm{~m}$ ). Each point represents a 30-min time period between March 26, 2011 and March 26, 2012, and includes both daytime and nighttime values. The resulting regression equation was used to fill gaps in ET data resulting from filtering or missing data. 
Systematic uncertainty of ET estimates derives primarily from the collective effects of inherent instrument measurement errors on density corrections (Webb et al., 1980; Webb, Pearman and Leuning Correction [WPL]). Uncertainty introduced by applying the WPL correction under the range of inherent measurement errors for each instrument (sensor) was estimated by defining a likely relative uncertainty for each independent parameter (instrument measurement) and by applying this, in turn, to calculate annual ET. Assuming that the various component uncertainties are independent, the combined uncertainty from the WPL correction was calculated by taking the square root of the sum of the squared individual uncertainties. Based on manufacturers' specifications, and on past experience with long-term sensor stability, the water vapor density, and static air pressure were assigned uncertainties of 10 percent (Wohlfahrt et al., 2008) while air temperature was assigned an uncertainty of 2 percent (Table 1). Uncertainty in the sensible heat flux may arise from the fact that the sensible heat flux was measured based on speed of sound measurements, which has been shown by Loescher et al. (2005) to deviate from sensible heat flux derived from measurements of air temperature with a fast-response platinum resistance thermometer by up to 10 percent for this specific sonic anemometer model. Alternatively, Ham and Heilman (2003) - again for the same anemometer model used in this study - found extremely close correspondence between sonic- and thermocouple-derived sensible heat flux measurements. Additional uncertainty of the sensible heat flux arises from the choice of coordinate system (Lee et al., 2004) and from the necessary (small) frequency response corrections (Massman, 2001). Based on the research findings

Table 1. Total systematic uncertainty of annual evapotranspiration ( $\mathrm{mm}$ ) calculated as the square root of the sum of squared individual sources of uncertainty. $\mathrm{T}_{\text {air }}-$ air temperature; $\rho \mathrm{v}-\mathrm{H}_{2} \mathrm{O}$ density; $\mathrm{P}$ - air pressure; $\mathrm{F}_{\mathrm{H}}$ - sensible heat before accounting for density effect and storage flux; $F_{\mathrm{LE}}$ - latent energy before accounting for density effects and storage flux.

\begin{tabular}{|c|c|c|}
\hline Source of uncertainty & Sagebrush & Pinyon Pine/Juniper \\
\hline $\mathrm{T}_{\mathrm{air}} \quad(2 \%)$ & 0.13 & 0.12 \\
\hline$\rho_{\mathrm{v}} \quad(10 \%)$ & 2.28 & 2.66 \\
\hline $\mathrm{P} \quad(10 \%)$ & 0.19 & 0.20 \\
\hline $\mathrm{F}_{\mathrm{H}} \quad(5 \%)$ & 1.03 & 1.19 \\
\hline $\mathrm{F}_{\mathrm{LE}} \quad(5 \%)$ & 13.66 & 15.70 \\
\hline Total systematic uncertainty (mm): & \pm 13.89 & \pm 15.97 \\
\hline
\end{tabular}


presented above and some preliminary sensitivity tests with different coordinate systems (data not shown), a 5 percent uncertainty for the sensible heat flux was assumed. Similar to the sensible heat flux, a 5 percent uncertainty for latent heat flux was assumed, intended to reflect uncertainties because of choice of the coordinate system and frequency response corrections, which are based on a site-specific co-spectral reference model (cf. Massman and Clement, 2004; Wohlfahrt et al., 2005) and have been validated against experimentally derived frequency response correction factors following Aubinet et al. (2000) and Aubinet et al. (2001) as described in Wohlfahrt et al. (2005) and Wohlfahrt et al. (2008). Based on this information, 5 percent uncertainty is justified and not nearly as large as the upper range of potential errors in frequency response correction factors (30 percent) reported by Massman and Clement (2004) (Table 1).

\section{AREA OF INTEREST FOOTPRINT ANALYSIS}

The area of interest footprint for each site (sagebrush [Figure 5] or pinyon pine/juniper [Figure 6] communities) was calculated using the footprint model of Hsieh et al. (2000) to estimate the upwind distance and compass direction that represented 90 percent of the surface flux for each half-hour period $\left(\mathrm{X}_{90 \%}\right)$. Close agreement between modeled and measured data from arid and agricultural areas has shown the model to be valid and provides reliable footprint data (Hsieh et al. 2000).

$$
\text { Error! Bookmark not defined. } X_{90 \%}=\frac{-D|L|^{(1-P)} Z_{u}^{P}}{k^{2} \ln (0.90)}
$$

Eq. 1

where $k$ is the von Karman constant (0.4), $L$ is the Obukhov length, and $Z_{u}$ is the length scale calculated as:

$$
Z_{u}=\frac{Z_{m} u k}{u_{*}} \quad \text { Eq. } 2
$$

where $Z_{m}$ is the measurement height, $u$ is the mean wind speed, and $D$ and $P$ are stabilitydependent coefficients:

$$
\begin{aligned}
& D=0.28 ; P=0.59 \text { for unstable conditions }\left(Z_{u} / L<-0.04\right) \\
& D=0.97 ; P=1.00 \text { for near-neutral conditions }\left(-0.04<Z_{u} / L<0.04\right)
\end{aligned}
$$


$D=2.44 ; P=1.33$ for stable conditions $\left(Z_{u} / L>0.04\right)$.

Each calculated point, or footprint distance and direction (that corresponds to an individual 30-min ET value), was then plotted in ArcGIS and a polygon circumscribed on the outside of the collective set of points that represented an area of interest (sagebrush or pinyon pine/juniper communities). Evapotranspiration for each area of interest was then calculated using ET values that were within the polygon and, therefore, representing ET from only the sagebrush or pinyon pine/juniper communities. Evapotranspiration values that were removed during this process were gap filled using the gap filling method previously described.

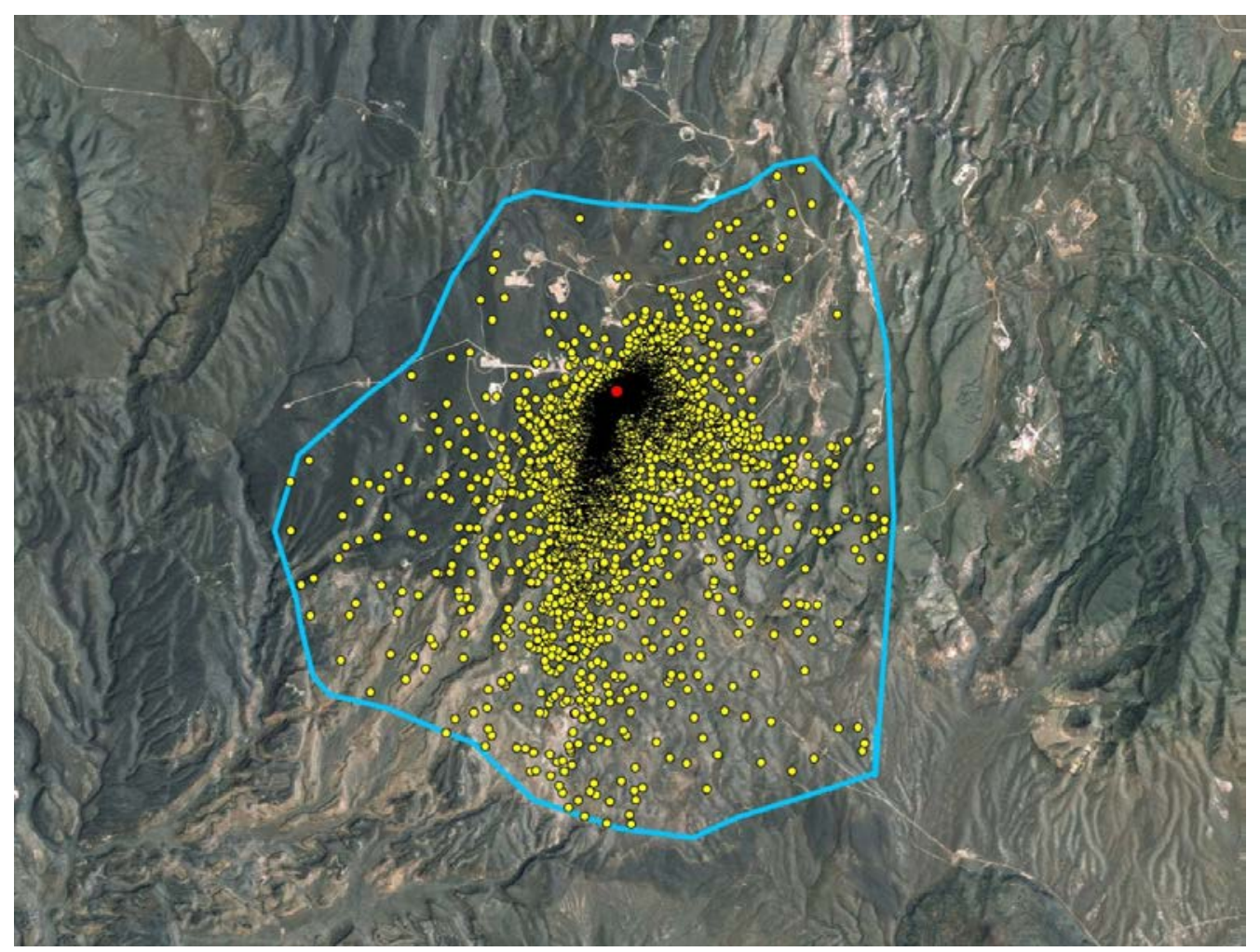

Figure 5. Area of interest footprint for the sagebrush site located at Pahute Mesa. The red dot indicates the location (elevation $1915 \mathrm{~m}$ ) of the eddy covariance tower. Yellow points represent individual 30-min flux values measured by the eddy covariance instrumentation between March 26, 2011 and March 26, 2012. The light blue line represents the area of interest footprint. 


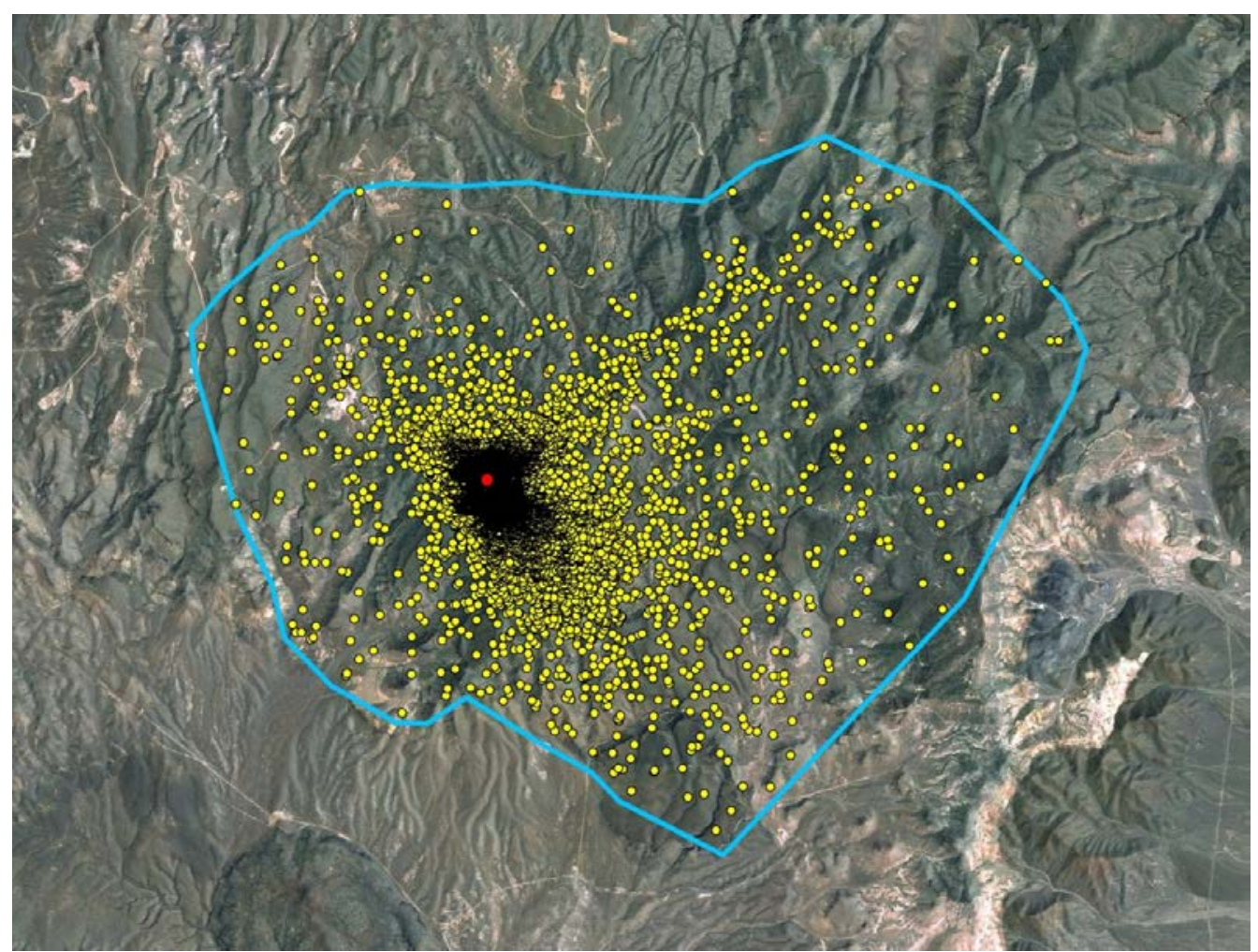

Figure 6. Area of interest footprint for the pinyon pine/juniper site located at Pahute Mesa. The red dot indicates the location (elevation $2223 \mathrm{~m}$ ) of the eddy covariance tower. Yellow points represent individual 30-min flux values measured by the eddy covariance instrumentation between March 26, 2011 and March 26, 2012. The light blue line represents the area of interest footprint.

\section{AIR TEMPERATURE, SOIL TEMPERATURE AND MOISTURE, NET RADIATION, AND PRECIPITATION DATA}

Mean daily air temperature, soil temperature, soil moisture, and net radiation were calculated by averaging all forty-eight half-hourly values for each day between March 26, 2011 and March 26, 2012 (Figure 7). At the sagebrush site, mean daily air temperature ranged from -6.4 to $25.9{ }^{\circ} \mathrm{C}$; mean daily soil temperature ranged from -2.4 to $28.7^{\circ} \mathrm{C}$; mean daily soil moisture ranged from 7.3 to 28 percent; and net radiation ranged from -23.5 to $215.7 \mathrm{~W} \mathrm{~m}^{-2}$. At the pinyon pine/juniper site, daily air temperature ranged from -7.7 to $24.1^{\circ} \mathrm{C}$; mean daily soil temperature ranged from -5.6 to $28.9^{\circ} \mathrm{C}$; mean daily soil moisture ranged from 7.9 to 43 percent; and net radiation ranged from -48.7 to $174 \mathrm{~W} \mathrm{~m}^{-2}$. Precipitation was measured at these sites with an unheated tipping bucket gauge for one year between March 26, 2011 and March 26, 2012; precipitation was $179 \mathrm{~mm}$ at the sagebrush site and $159 \mathrm{~mm}$ at the pinyon pine/juniper site (Table 2). Precipitation also was measured with bulk gauges between March 21, 2011 and March 
28, 2012; precipitation from the bulk gauges was $222 \mathrm{~mm}$ at the sagebrush site and $227 \mathrm{~mm}$ at the pinyon pine/juniper site. Average annual air temperature, vapor pressure, vapor pressure deficit, and soil temperature (average depth was $4 \mathrm{~cm}$ ) are listed in Table 2.
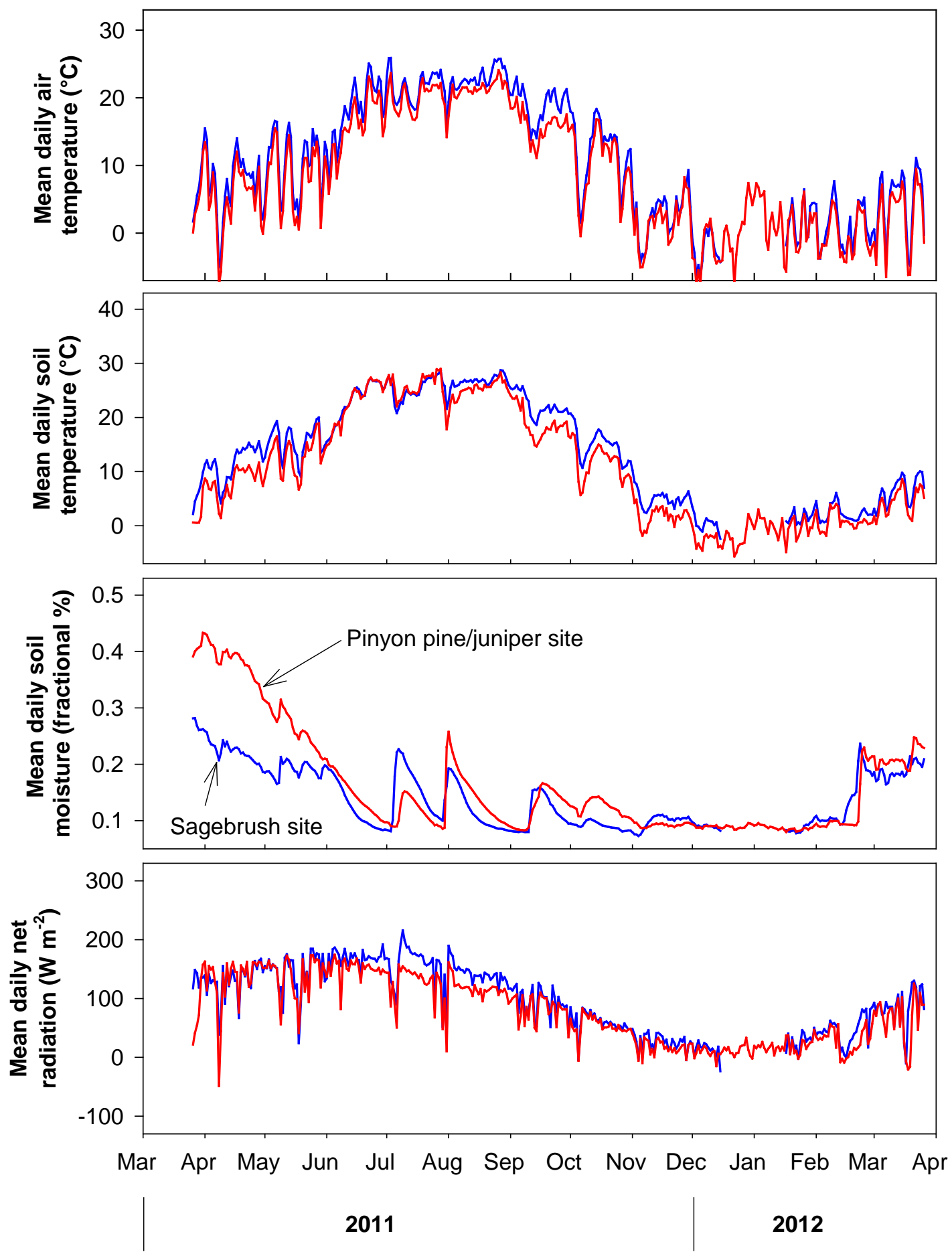

Figure 7. Mean daily air temperature, soil temperature, soil moisture, and net radiation measured at the sagebrush (blue line) and pinyon pine juniper (red line) sites located at Pahute Mesa between March 26, 2011 and March 26, 2012. 
Table 2. Study-year: average air temperature, air vapor pressure, air vapor pressure deficit, soil temperature, and total precipitation for the sagebrush and pinyon pine/juniper sites.

\begin{tabular}{|c|c|c|}
\hline Characteristic & Sagebrush & Pinyon Pine/Juniper \\
\hline Air temperature $\left({ }^{\circ} \mathrm{C}\right)$ & 10.9 & 8.5 \\
\hline Vapor pressure $(\mathrm{kPa})$ & 0.11 & 0.15 \\
\hline Air vapor pressure deficit $(\mathrm{kPa})$ & 1.20 & 0.96 \\
\hline Soil temperature $\left({ }^{\circ} \mathrm{C}\right)$ & 14.0 & 10.8 \\
\hline Tipping bucket precipitation (mm) & $179 \ddagger$ & 159 \\
\hline Bulk gauge precipitation (mm) & $222 *$ & $227 * *$ \\
\hline \multicolumn{3}{|c|}{$\begin{array}{l}\dagger \text { Precipitation was measured using an unheated tipping bucket rain gauge; therefore, the total } \\
\text { amount of precipitation may be underestimated, especially during periods of frozen precipitation }\end{array}$} \\
\hline
\end{tabular}

\section{EVAPOTRANSPIRATION DATA}

Daily ET was calculated for each site by summing the individual 30-min values for each day (48 30-min values per day). Maximum daily ET at the sagebrush site was $6.0 \mathrm{~mm}$ /day and $3.3 \mathrm{~mm} /$ day at the pinyon pine/juniper site (Figure 8). Daily ET increased immediately after precipitation events (Figure 8). An example of the response of energy fluxes to these precipitation events at the sagebrush site during July, 2011 is presented in Figure 9. Before precipitation occurred, latent energy (LE) was 87 percent lower than sensible heat (H) (Figure 9) indicating that most of the energy was going toward $\mathrm{H}$ flux and that soils were relatively dry with limited water available for evaporation and plant transpiration. After precipitation occurred, $\mathrm{LE}$ became greater than $\mathrm{H}$ (a maximum difference of 42 percent between these two energy fluxes occurred during the time period presented in Figure 9) indicating LE was the major energy flux during this time (Figure 9). Latent energy started to decrease as the amount of available soil moisture began to decrease and by the last three days of the July time period, $\mathrm{H}$ flux was again greater than LE flux as it had been prior to the precipitation events. Monthly ET was calculated by summing all daily values for each month (Table 3). The highest monthly ET occurred in July for the sagebrush site and May for the pinyon pine/juniper site. The lowest monthly ET occurred in December for both study sites. Annual ET was calculated by summing all monthly values (Table 3). Annual ET was $310 \pm 13.9$ and $347 \pm 15.9 \mathrm{~mm}$ for the sagebrush and pinyon pine/juniper sites, respectively (Table 3). 
Annual ET at both sites exceeded tipping bucket precipitation gauge (179 $\mathrm{mm}$ for the sagebrush site and $159 \mathrm{~mm}$ for the pinyon pine/juniper site) and bulk precipitation gauge (222 $\mathrm{mm}$ for the sagebrush site and $227 \mathrm{~mm}$ for the pinyon pine/juniper site) annual precipitation (Table 1). Annual ET exceeded annual precipitation at both sites because the precipitation gauges and EC instrumentation did not start collecting data until March 26, 2011. By this date, significant amounts of precipitation had already fallen at both sites between October 1, 2010 (the start of the hydrologic year) and March 26, 2011 (the first day of data collection at the sites); therefore, estimates of ET presented here include precipitation that fell prior to, and during, EC data collection. Precipitation data for Pahute Mesa for this time period are incomplete (http://www.sord.nv.doe.gov/raingage/Monthly/Pahute_Mesa_Monthly_Data.txt) so the actual amount of precipitation that fell prior to installation of instrumentation at the EC sites could not be quantified. However, other precipitation stations at the NNSS show significant amounts of precipitation likely had fallen at the EC sites from October 2010 through March 2011 (Table 4), particularly in October and again in December.

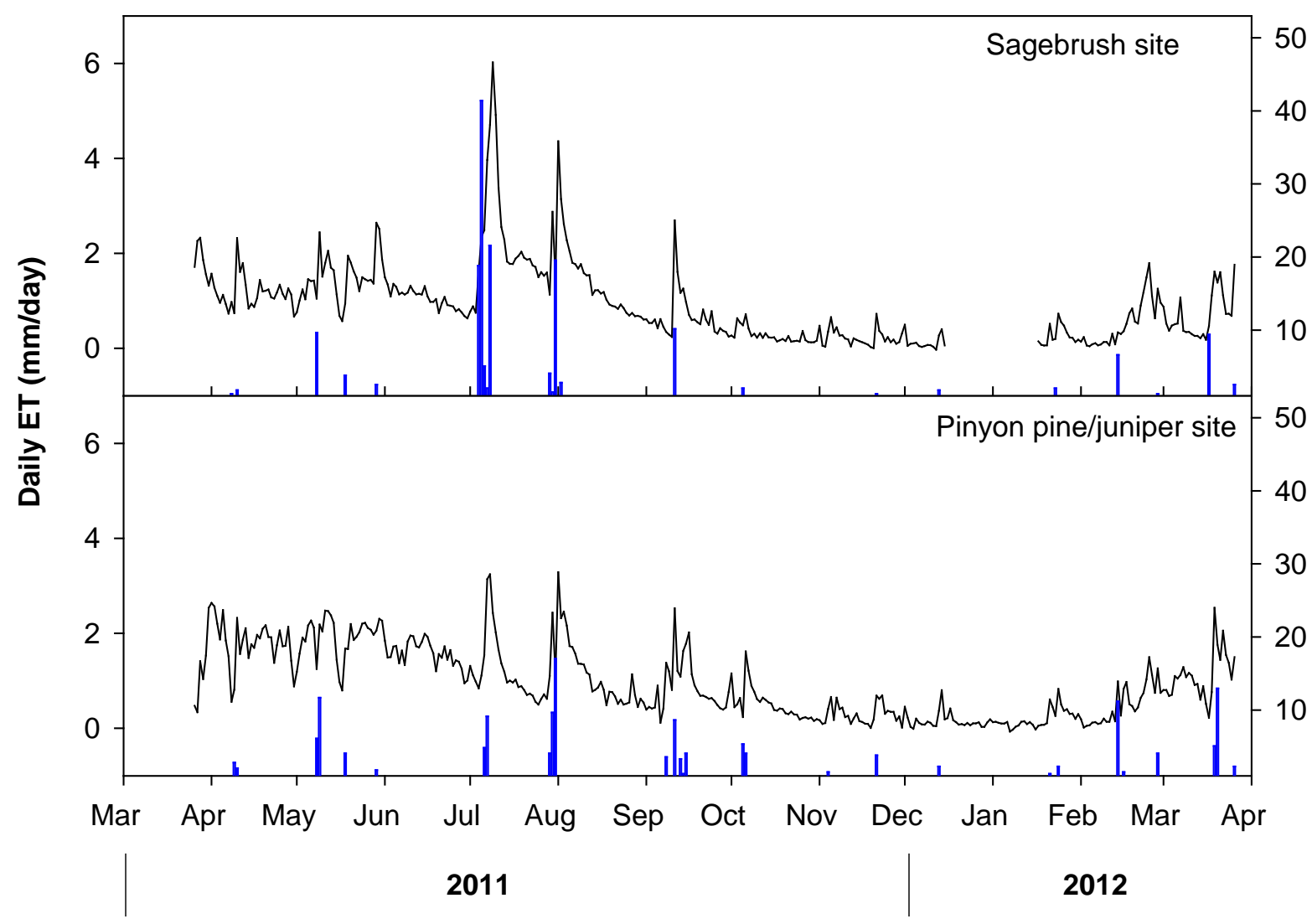

Figure 8. Daily evapotranspiration (ET) (black line) and daily precipitation (blue bars) for the sagebrush and pinyon pine/juniper sites located at Pahute Mesa during the one-year study (March 26, 2011 and March 26, 2012). Daily precipitation, measured by an unheated tipping bucket rain gauge, was calculated by summing all forty-eight half-hourly values for each day. It should be noted that unheated tipping bucket rain gauges can underestimate frozen precipitation, and, therefore, 
the data from these gauges should be used with caution; however, tipping bucket precipitation data are presented in this figure to show the response of daily ET to precipitation events and not necessarily for absolute precipitation amounts.

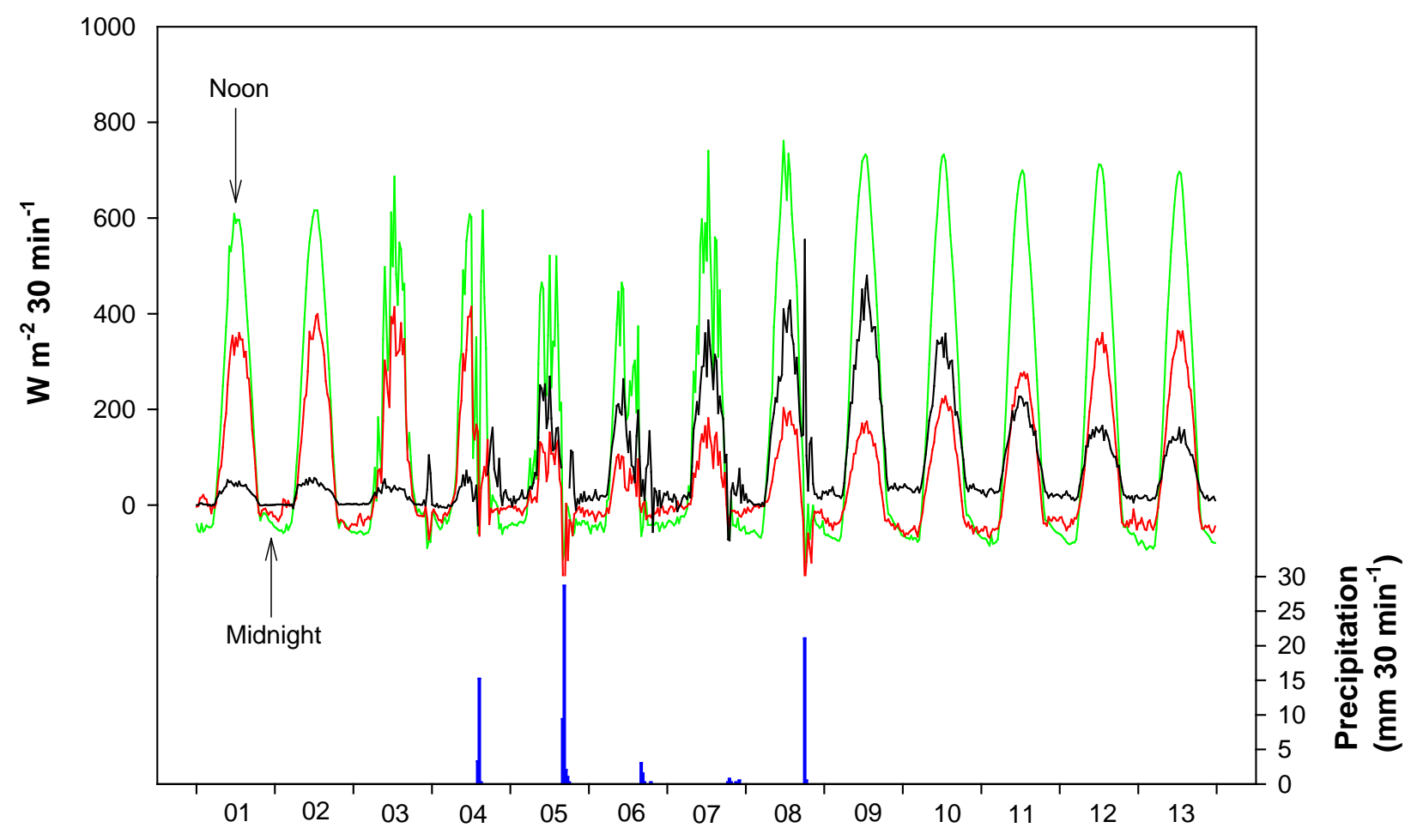

July 2011

Figure 9. Response of available energy (green line), latent energy (LE; black line), and sensible heat ( $\mathrm{H}$; red line) fluxes to precipitation events (blue bars) between the dates of July 1 and July 13, 2011 at the sagebrush site located on Pahute Mesa.

\section{COMPARISON OF TIPPING BUCKET AND BULK GAUGE PRECIPITATION DATA}

Both the sagebrush and pinyon pine/juniper sites contained a bulk precipitation gauge and an unheated tipping bucket precipitation gauge. Bulk precipitation measurements were taken manually approximately once per month during the one-year study while the tipping bucket precipitation gauges automatically logged individual 30-min sums of precipitation throughout the year-long study to the CR5000 data logger and compact flash card at each site. Total precipitation measured by the unheated tipping bucket precipitation gauge was 17 and 20 percent lower than precipitation measured with the bulk precipitation gauge for the sagebrush and pinyon pine/juniper sites, respectively (Table 5). The lower amounts of precipitation measured at both study sites by the unheated tipping bucket precipitation gauge is most likely because the unheated tipping bucket precipitation gauge did not measure frozen precipitation as accurately as the bulk precipitation gauge. 
Table 3. Monthly evapotranspiration (ET) values ( $\mathrm{mm} / \mathrm{month}$ ) for the sagebrush and pinyon pine/juniper sites located at Pahute Mesa between March 26, 2011 and March 26, 2012.

\begin{tabular}{lcc}
\hline & \multicolumn{2}{c}{$\begin{array}{c}\text { Monthly Evapotrans piration } \\
\text { (mm/month) }\end{array}$} \\
\hline \multicolumn{1}{c}{ Month } & Site \\
\cline { 2 - 3 } 2011 & Sagebrush & Pinyon pine/juniper \\
March $\dagger$ & 11.0 & 7.3 \\
April & 35.2 & 54.4 \\
May & 46.1 & 59.9 \\
June & 31.7 & 47.2 \\
July & 68.8 & 38.3 \\
August & 43.2 & 34.7 \\
September & 20.1 & 26.0 \\
October & 8.2 & 15.5 \\
November & 6.8 & 8.7 \\
December & $1.9 *$ & 5.0 \\
2012 & & 6.1 \\
January & $4.1 \neq$ & 14.4 \\
February & 15.1 & 29.0 \\
March** & 18.1 & 346.5 \\
\hline Annual ET (mm) & $\mathbf{3 1 0 . 3}$ & \\
\hline
\end{tabular}

† Data collection did not start until March 26, 2011

* Missing data because of flash card reader error (data range, December 1 - 14)

$\ddagger$ Missing data because of flash card reader error (data range, January 17 - 31)

** March 26, 2012 - last day of data collection 
Table 4. Precipitation data for select gauges at the NNSS from October 2010 through March 2011 (http://www.sord.nv.doe.gov/home_climate_rain.htm).

\begin{tabular}{|c|c|c|c|c|c|c|c|}
\hline & $\begin{array}{l}\text { Oct } \\
(\mathrm{mm})\end{array}$ & $\begin{array}{l}\text { Nov } \\
(\mathrm{mm})\end{array}$ & $\begin{array}{c}\text { Dec } \\
(\mathrm{mm})\end{array}$ & $\begin{array}{c}\text { Jan } \\
(\mathrm{mm})\end{array}$ & $\begin{array}{l}\text { Feb } \\
(\mathrm{mm})\end{array}$ & $\begin{array}{l}\text { Mar } \\
(\mathrm{mm})\end{array}$ & $\begin{array}{c}\text { 6-month total } \\
(\mathrm{mm})\end{array}$ \\
\hline Precipitation Gauge & $\begin{array}{c}\text { Latitude } \\
\text { (deg min sec) }\end{array}$ & $\begin{array}{c}\text { Longitude } \\
\text { (deg min sec) }\end{array}$ & $\begin{array}{l}\text { Elevation } \\
\text { (m) }\end{array}$ & & & & \\
\hline RAINIER MESA & $371128.6 \mathrm{~N}$ & $1161258.7 \mathrm{~W}$ & 2298 & & & & \\
\hline 2010 & 49 & 24 & 153 & - & - & - & - \\
\hline 2011 & - & - & - & 6 & 33 & 47 & 312 \\
\hline Average & 14 & 26 & 27 & 41 & 43 & 49 & 201 \\
\hline Percent of Average & 345 & 91 & 556 & 16 & 76 & 97 & 156 \\
\hline E TUNNEL & $371118.0 \mathrm{~N}$ & $1161138.9 \mathrm{~W}$ & 1856 & & & & \\
\hline 2010 & 61 & 25 & 148 & - & - & - & - \\
\hline 2011 & - & - & - & 8 & 35 & 49 & 325 \\
\hline Average & 20 & 16 & 37 & 33 & 62 & 26 & 195 \\
\hline Percent & 301 & 156 & 401 & 24 & 56 & 184 & 167 \\
\hline \multirow[t]{2}{*}{ TIPPIPAH SPRING } & $370230 \mathrm{~N}$ & $1161407 \mathrm{~W}$ & 1667 & \multicolumn{2}{|c|}{ (until 09/28/1964) } & & \\
\hline & $370307.8 \mathrm{~N}$ & $1161139.7 \mathrm{~W}$ & 1506 & (as of 0 & 8/1964) & & \\
\hline 2010 & 39 & 8 & 92 & - & - & - & - \\
\hline 2011 & - & - & - & 5 & 19 & 23 & 186 \\
\hline Average & 12 & 16 & 22 & 28 & 36 & 26 & 140 \\
\hline Percent & 317 & 50 & 414 & 17 & 53 & 88 & 132 \\
\hline YUCCA DRY LAKE & $365722.2 \mathrm{~N}$ & $1160300.0 \mathrm{~W}$ & 1178 & & & & \\
\hline 2010 & 27 & 1 & 115 & - & - & - & \\
\hline 2011 & - & - & - & 4 & 12 & 18 & 177 \\
\hline Average & 9 & 13 & 18 & 24 & 25 & 18 & 107 \\
\hline Percent & 309 & 4 & 628 & 17 & 48 & 99 & 165 \\
\hline
\end{tabular}


Table 5. Comparison of unheated tipping bucket and bulk precipitation gauges located at both the sagebrush and pinyon pine/juniper sites at Pahute Mesa, Nevada.

Because of a slight difference in the start (5 days) and end date (1 day) of data collection from the two types of gauges, and to make a fair comparison, data were only used from dates that were in common for the two types of measurement methods.

\begin{tabular}{lcccc}
\hline \multicolumn{1}{c}{ Date range } & \multicolumn{2}{c}{$\begin{array}{c}\text { Sagebrush Site } \\
\text { Unheated tipping } \\
\text { bucket gauge } \\
(\mathrm{mm})\end{array}$} & $\begin{array}{c}\text { Pinyon Pine/Juniper Site } \\
\text { Bulk gauge } \\
(\mathrm{mm})\end{array}$ & $\begin{array}{c}\text { Unheated tipping } \\
\text { bucket gauge } \\
(\mathrm{mm})\end{array}$ \\
\hline $\mathbf{2 0 1 1}$ & & & & \\
April 25 - May 31 & 25.4 & 16.3 & 34.9 & 23.9 \\
June 1 - June 29 & 0.0 & 0.0 & 0.0 & 0.3 \\
June 30 - August 2 & 104.8 & 116.8 & 44.5 & 45.5 \\
August 3 - September 8 & 15.9 & 0.0 & 4.8 & 4.3 \\
September 9 - October 17 & 6.4 & 14.7 & 27.0 & 29.0 \\
October 18 - November 15 & 3.2 & 0.8 & 0.0 & 2.3 \\
November 16 - December 15 & 4.8 & 3.0 & 6.4 & 6.4 \\
2012 & & & & \\
January 18 - February 23 & 33.3 & 9.9 & 42.9 & 16.8 \\
\hline Total precipitation & $\mathbf{1 9 3 . 8}$ & $\mathbf{1 6 1 . 5}$ & $\mathbf{1 6 0 . 5}$ & $\mathbf{1 2 8 . 5}$ \\
\hline
\end{tabular}

\section{SUMMARY}

To provide data for the Pahute Mesa INFIL3.0 recharge model, two EC stations, along with meteorological and energy balance instrumentation, were installed on Pahute Mesa to estimate ET. The EC method was used to estimate ET for one year at two predominant plant communities (sagebrush and pinyon pine/juniper) on Pahute Mesa. Estimated annual ET at the sagebrush site during the one-year study was $310 \pm 13.9 \mathrm{~mm}$ while at the pinyon pine/juniper site annual ET was $347 \pm 15.9 \mathrm{~mm}$. Precipitation was measured at each site using an unheated tipping bucket precipitation gauge and a bulk precipitation gauge. Annual precipitation from the sagebrush site was 222 and $179 \mathrm{~mm}$ from the bulk and tipping bucket gauges, respectively. Annual precipitation from the pinyon pine/juniper site was 227 and $159 \mathrm{~mm}$ from the bulk and tipping bucket precipitation gauges, respectively. Precipitation measured with the tipping bucket precipitation gauge was 17 percent lower than the bulk precipitation gauge at the sagebrush site and 20 percent lower at the pinyon pine/juniper site. Differences in precipitation measured using the two gauges were most likely caused by the tipping bucket precipitation gauge not measuring frozen precipitation as accurately as the bulk precipitation gauge and inherent tipping bucket measurement errors (e.g., evaporation from the tipping bucket spoon). In this one-year study, evapotranspiration exceeded precipitation at both study sites because estimates of evapotranspiration included precipitation that fell during the winter of 2010-2011 prior to installation of EC instrumentation in late March 2011. 


\section{REFERENCES}

Aubinet, M., A. Grelle, and A. Ibrom, U. Rannik, J. Moncrieff, T. Foken, A.S. Kowalski, P.H. Martin, P. Berbigier, Ch. Bernhofer, R. Clement, J. Elbers, A. Granier, T. Grundwald, K. Morgenstern, K. Pilegaard, C. Rebmann, W. Snijders, R. Valentini, and T. Vesala, 2000. Estimates of the annual net carbon and water exchange of forest: the EUROFLUX methodology. Advances in Ecological Research, 30:113-175.

Aubinet, M., B. Chermanne, M. Vandenhaute, B. Longdoz , M. Yernaux, and E. Laitat, 2001. Long term carbon dioxide exchange above a mixed forest in the Belgian Ardennes. Agricultural and Forest Meteorology, 108:293-315.

Falge E., D. Baldocchi, R.J. Olson et al. (2001) Gap filling strategies for defensible annual sums of net ecosystem exchange. Agricultural and Forest Meteorology, 107:43-69.

Foken, Th., and B. Wichura, 1996. Tools for quality assessment of surface-based flux measurements. Agricultural and Forest Meteorology, 78:83-105.

Foken, Th., M. Göckede, M. Mauder, L. Mahrt, B. Amiro, and W. Munger, 2004. Post-field Data Quality Control. Handbook of Micrometeorology, X. Lee, W. Massman, and B. Law, editors, pp. 181-208. Kluwer Academic Publishers, Dordrecht, The Netherlands.

Gash, J.H.C. and A.J. Dolman, 2003. Sonic anemometer (co)sine response and flux measurement I. potential for (co)sine error to affect sonic anemometer-based flux measurements. Agricultural and Forest Meteorology, 119:195-207.

Geissbühler, P., R. Siegwolf, and W. Eugster, 2000. Eddy covariance measurements on mountain slopes: the advantage of surface-normal sensor orientation over a vertical set-up. Boundary-Layer Meteorology, 96:317-392.

Ham, J.M., and J.L. Heilman, 2003. Experimental test of density and energy-balance corrections on carbon dioxide flux as measured using open-path eddy covariance. Agronomy Journal, 95:1393-1403.

Hevesi, J.A., A.L. Flint, L.E. and Flint, 2003, Simulation of Net Infiltration and Potential Recharge Using a Distributed-Parameter Watershed Model of the Death Valley Region, Nevada and California. U.S. Geological Survey Water-Resources Investigations Report 03-4090, 171 p. http://pubs.usgs.gov/wri/wri034090/.

Hsieh, C.I., G. Katul, and T.W. Chi, 2000. An approximate analytical model for footprint estimation of scalar fluxes in thermally stratified atmospheric flows. Advances in Water Resources, 23:765-772.

Kaimal, J.C., and J.J. Finnigan, 1994. Atmospheric boundary layer flows: Their structure and measurement. Oxford University Press. New York, NY, p. 289.

Lee, X., J. Finnigan, and K.T. Paw U, 2004. Coordinate Systems and Flux Bias Error. Handbook of Micrometeorology. X. Lee, W. Massman, and B. Law, editors, Kluwer Academic Publishers, New York, p. 33-66. 
Loescher, H.W., T. Ocheltree, and B. Tanner, E. Swiatek, B. Dano, J Wong, G. Zimmerman, J. Campbell, C. Stock, L. Jacobson, Y. Shiga, J. Kollas, J. Liburby, and B.E. Law, 2005. Comparison of temperature and wind statistics in contrasting environments among different sonic anemometer-thermometers. Agricultural and Forest Meteorology, 133:119-139.

Massman, W.J., 2000. A simple method for estimating frequency response corrections for eddy covariance systems. Agricultural and Forest Meteorology, 104:185-198.

Massman, W.J., 2001. Reply to comment by Rannik on “A simple method for estimating frequency response corrections for eddy covariance systems.” Agricultural and Forest Meteorology, 107:247-251.

Massman, W.J., and R. Clement, 2004. Uncertainty in Eddy Covariance Flux Estimates Resulting from Spectral Attenuation. Handbook of Micrometeorology. X. Lee, W. Massman, and B. Law, editors, Kluwer Academic Publishers, New York, 67-100.

U.S. Department of Energy, 2009. Phase II Corrective Action Investigation Plan for Corrective Action Units 101 and 102: Central and Western Pahute Mesa, Nevada Test Site, Nye County, Nevada. U.S. Department of Energy, National Nuclear Security Administration, Nevada Site Office, Las Vegas, Nevada, Revision No.: 2, July 2009, DOE/NV--1312Rev. 2.

U.S. Geological Survey, 2008. Documentation of Computer Program INFIL3.0-A DistributedParameter Watershed Model to Estimate Net Infiltration below the Root Zone. U.S. Geological Survey Investigations Report 2008-5006, 98 p. http://water.usgs.gov/nrp/gwsoftware/Infil/Infil.html.

Webb, E.K., G.I. Pearman, and R. Leuning, 1980. Correction of flux measurements for density effects due to heat and water vapour transfer. Quarterly Journal of the Royal Meteorological Society, 106:85-100.

Wohlfahrt, G., C. Anfang, M. Bahn, A. Haslwanter, C. Newesely, M. Schmitt, M. Drosler, J. Pfadenhauer, and A. Cernusca, 2005. Quantifying nighttime ecosystem respiration of a meadow using eddy covariance, chambers and modeling. Agricultural and Forest Meteorology, 128:141-162.

Wohlfahrt, G., J.A. Arnone III, and L.F. Fenstermaker, 2008. Large annual net ecosystem $\mathrm{CO}_{2}$ uptake of a Mojave Desert ecosystem. Global Change Biology, 14:1475-1487. 